\title{
Knowledge Acquisition for Engineering Decisions Based on Functional Relationships
}

\author{
Larisa Simonova $^{1}$, Elena Egorova ${ }^{2}$, Aidar Akhmadiev $^{3}$ \\ ${ }^{1}$ Kazan Federal University, Russia \\ ${ }^{2}$ Kazan National Research Technical University A.N. Tupolev - KAI, Russia \\ ${ }^{3}$ Kazan National Research Technical University A.N. Tupolev - KAI, Russia
}

\begin{abstract}
This article is devoted to formation of a subject of engineering decision in intelligent system of development of production processes based on description of functional models of engineering capabilities upon decision making. A subject of design engineering decision is a complicated system including subsystems of various essence, which operate according to rules described by fizzy logics and study cases. Design engineering decision is formed as a consequence of combined operation of intelligent system modules: equipment selection module, tool selection module, and accessory selection module. Each module of design engineering decision is characterized by its unique properties of engineering design both at input and output of decision formation. Therefore, each module of intelligent system of development of production processes is considered as a complex system with inherent properties. The components of a given specific system, for instance, selection of metal cutting equipment, will be input parameters for specific system module. Output parameters of the system of selection of metal cutting equipment will be input parameters for the system of selection of cutting tools, etc.
\end{abstract}

Key words: artificial intelligence, engineering decision, fuzzy logics, cutting tools, production process.

\section{INTRODUCTION}

Integrated systems in engineering were analyzed in [1, 2], which allowed to conclude that during selection of processing strategy, the important issues for technologist were such components of design system as machine, accessory, and cutting tools. Correct selection of each design component influences the processing quality of overall item and competitiveness of production with accounting for subjective rational selection at each design stage. The procedure of object-oriented approach to formalized decision to processing strategy was described in [3,4].

While forming the optimum engineering decision, let us consider each component of decision making as a separate system with its properties, input and output parameters of designing procedure aiming at detection of common designing properties and development of functional models of engineering capabilities upon decision making $[3,5]$. It is proposed in [6] to consider a designed item in terms of variation of production processes. With this aim, in [7] the technology was proposed to present data about an item based on its design and engineering properties.

\section{METHODS}

Operation of an intelligent system should be based on rules and case database, which present functional relationships of engineering decision making under certain production conditions. The case database stores patterns of engineering decision on processing of specified design element including the stages of formation of engineering decision.

Formation stages of engineering decision, which are generated nearly automatically by technologist mentality on the basis of his/her experience and knowledge for development of intelligent system of engineering process design, are multivariate multilevel task with numerous parameters both for input into and output from the system, as well as interaction inside the system (Fig. 2).

\section{RESULTS AND DISCUSSION}

At the stage of engineering preparation of production during heuristic design of item processing, a technologist responds to the following questions: How the workpiece should be processed? Using what tools? How the item should be fixed? What metal cutting equipment should be applied? In other words, the elements of design system, such as machine-accessory-tool, become the major solvable tasks of engineering design.

Let us consider functional models of each design module of intelligent system [4] individually due to complexity of designing (Fig. 1). 


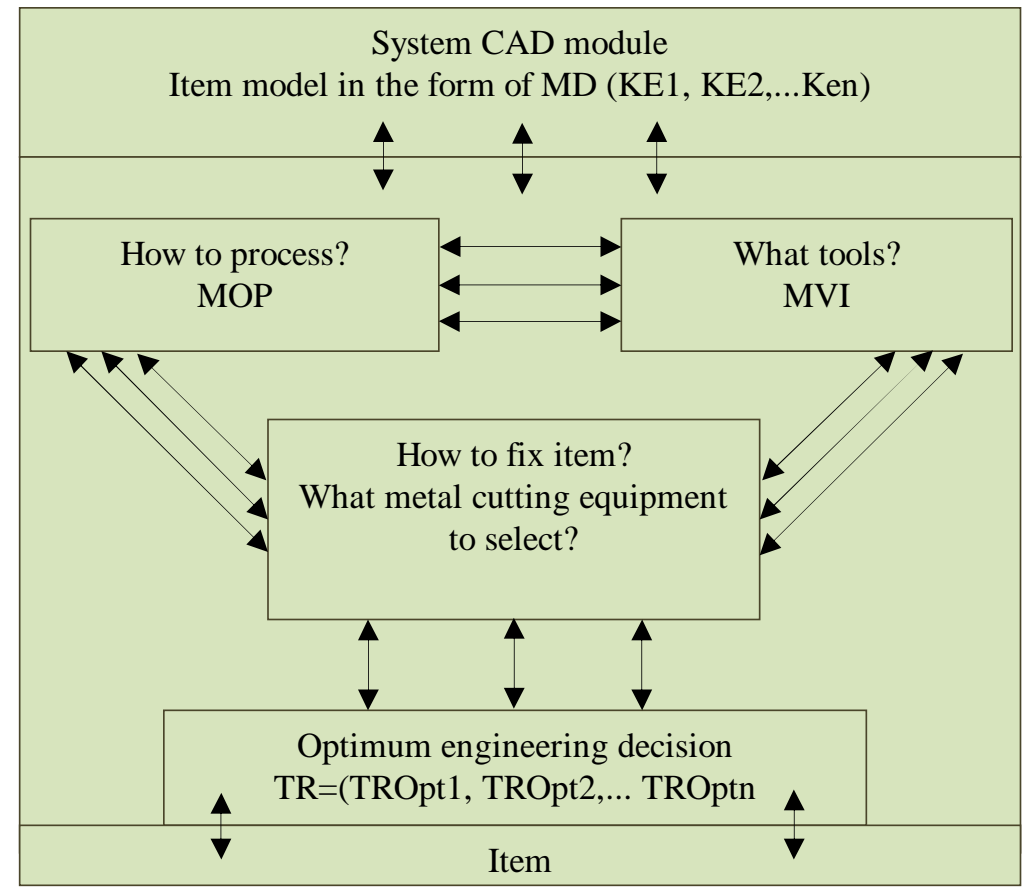

Figure 1: Interaction of system modules

The module of selection of metal cutting equipment $(\mathrm{MVPr}+\mathrm{O})$ is preceded by design tasks related with processing of engineering decisions aimed at selection of routes of design element processing (MOP) as a complete and indivisible part of item decomposition into finite set of elements (Figure 2), and selection of cutting tools (MVI).

In the transformation module, the work drawing is presented in the form of interrelation graph and tables containing data about fitting of all junctions, sets of main and auxiliary databases with predefined level of precision and surface roughness [6]. At the stage of specification of a new item, the technologist should accurately and quickly determine expected labor consumption of item production, demands for engineering tools, as well as possibility of its production under given production conditions (Figure 2).

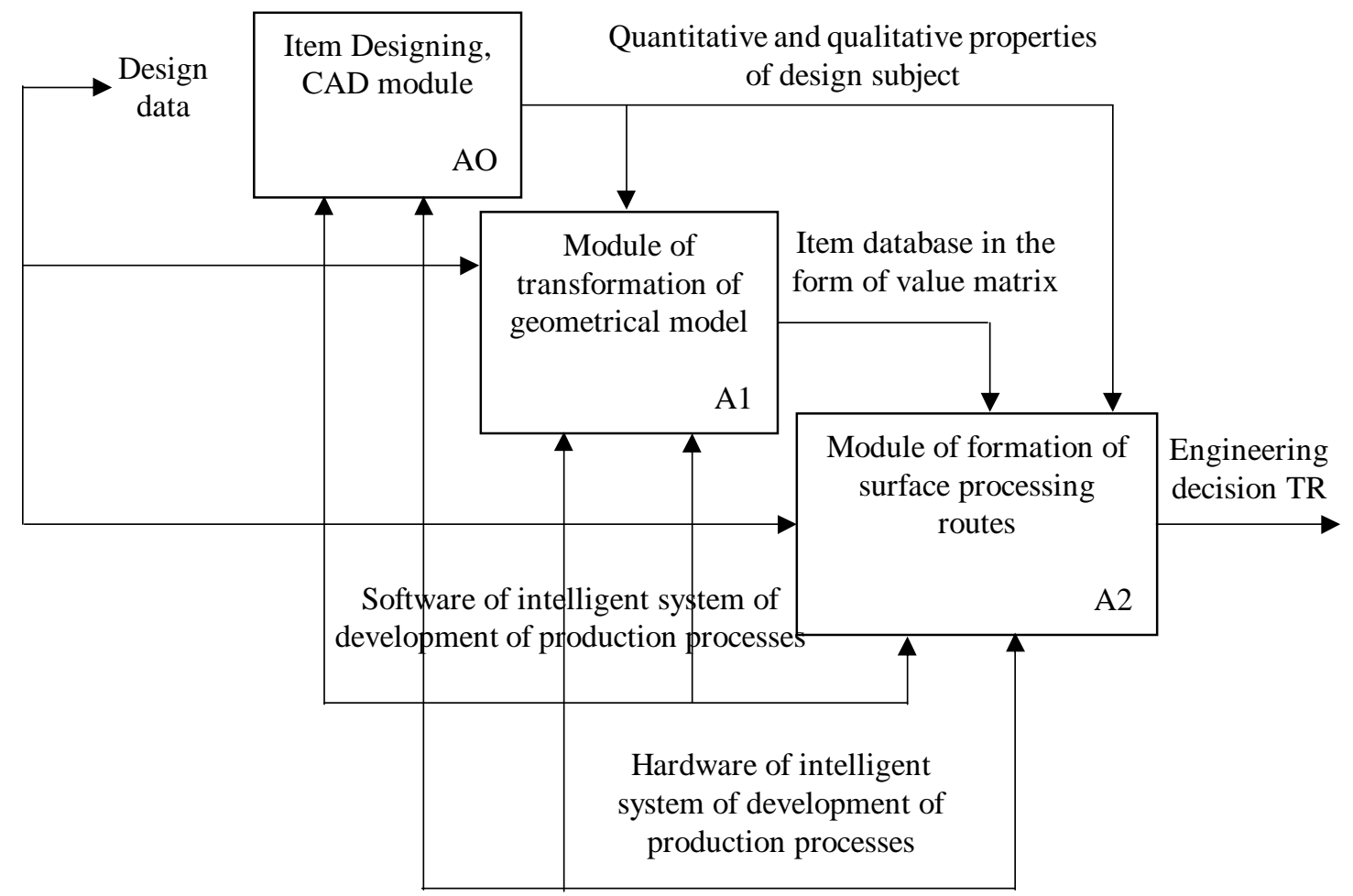

Figure 2: Functional model. 
Larisa Simonova et al., International Journal of Emerging Trends in Engineering Research, 8(6), June 2020, 2774- 2778

The module of formation of surface processing routes (MOP) operates according to the rules based on the logical operators AND, OR, IF and linguistic variables, such as TO DRILL, TO MILL, TO GRIND, TO COUNTERSINK, TO REAM, TO BORE, etc. The linguistic variables are assigned to numerical values, which are contained in the tables of description of design element. A rule is comprised of condition and action related with fuzzy logics. Unique interpretation of transition from fuzzy variables to actual parameters is based on the correspondence tables of engineering capabilities [7].

Let us consider an example of formation of hole processing route. The design element (DE), HOLE, is described by the correspondence table containing numerical values (Table 1).

Table 1: Input parameters for Hole DE

\begin{tabular}{|l|l|l|l|l|}
\hline & $\begin{array}{l}\text { Diameter, } \\
\mathrm{mm}\end{array}$ & $\begin{array}{l}\text { Depth, } \\
\mathrm{mm}\end{array}$ & IT & Ra \\
\hline Hole DE & 5.2 & 12 & 11 & 6.3 \\
\hline
\end{tabular}

According to State standard GOST 3.1702-79, the following transitions are assigned to HOLE DE:

1. To countersink: Code 10

2. To ream: Code 22

3. To ream: - Code 25

4. To bore: Code 26

5. To drill: Code 27

6. To grind: Code 30

7. To counterbore: Code 34

8. To center: Code 35

9. To mill: Code 36

Using reference books, it is possible to determine that for

HOLE DE (Table 1), the following processing routes are possible:

1. Drilling - Processing accuracy 11-13 quality, Ra = 6.3-12.5 $\mu \mathrm{m}$

2. Rough milling - Processing accuracy 8-13 quality, $\mathrm{Ra}=$ 6.3-12.5 $\mu \mathrm{m}$

3. Final milling - Processing accuracy 7-11 quality, $\mathrm{Ra}=$ 3.2-6.3 $\mu \mathrm{m}$

4. Fine milling - Processing accuracy 6-9 quality, $\mathrm{Ra}=$ 1.25-3.2 $\mu \mathrm{m}$

5. Countersinking - Processing accuracy 9-10 quality, $\mathrm{Ra}=$ $1.25-3.2 \mu \mathrm{m}$

6. Reaming - Processing accuracy 6-7 quality, Ra = $0.2-1.25$

7. Boring.

The rule is as follows:

IF diameter is integer, THEN transition TO DRILL

IF diameter is fractional, THEN transition TO MILL

OR transition TO DRILL and TO MILL

IF transition contains logical AND, THEN, weighting factor 2 is assigned to it
IF transition does not contain logical AND, THEN, weighting factor 1 is assigned to it

The correspondence tables [1] of processing accuracy of preset roughness of HOLE DE for transitions TO DRILL and TO MILL are shown below in Tables $2 \mathrm{a}$ and $2 \mathrm{~b}$, respectively.

Table 2a: Processing precision of preset roughness

\begin{tabular}{|l|l|l|}
\hline Transition TO DRILL & \\
\hline IT / Ra & 6.3 & 12.5 \\
\hline 11 & + & - \\
\hline 11 & - & + \\
\hline 12 & + & - \\
\hline 12 & - & + \\
\hline 13 & + & - \\
\hline 13 & - & + \\
\hline
\end{tabular}

Table 2b: Processing precision of preset roughness

\begin{tabular}{|l|l|l|}
\hline \multicolumn{2}{|l|}{ Transition TO MILL } \\
\hline IT / Ra & 6.3 & 12.5 \\
\hline 8 & + & - \\
\hline 8 & - & + \\
\hline 9 & + & - \\
\hline 9 & - & + \\
\hline 10 & + & - \\
\hline 10 & - & + \\
\hline 11 & + & - \\
\hline 11 & - & + \\
\hline 12 & + & - \\
\hline 12 & - & + \\
\hline 13 & + & - \\
\hline 13 & - & + \\
\hline
\end{tabular}

On the basis of the input data (Table 1) and operation of formation module of surface processing route (Tables 2a, 2b), two engineering decisions will be formed with the following preference priorities (Table 3):

Table 3: MOP engineering decision

\begin{tabular}{|l|l|l|}
\hline Processing route of Hole DE & $\begin{array}{l}\text { Weightin } \\
\mathrm{g} \text { factor }\end{array}$ & $\begin{array}{l}\text { Engineerin } \\
\mathrm{g} \text { decisions }\end{array}$ \\
\hline $\begin{array}{l}\text { TO MILL a hole with the } \\
\text { diameter of } 5.2 \mathrm{~mm} \text { to the depth } \\
\text { of } 12 \mathrm{~mm}\end{array}$ & 1 & $\mathrm{TR} 1$ \\
\hline $\begin{array}{l}\text { TO DRILL a hole with the } \\
\text { diameter of } 5.2 \mathrm{~mm} \text { to the depth } \\
\text { of } 12 \mathrm{~mm} \text { preliminary } \\
\text { TO MILL a hole with the } \\
\text { diameter of } 5.2 \mathrm{~mm} \text { to the depth } \\
\text { of } 12 \mathrm{~mm} \text { finally }\end{array}$ & & \\
\hline
\end{tabular}

After formation of DE processing route based on ranking of weighting factors [2], the design module is initiated related with adjustment of engineering decision regarding selection of cutting tools (MVI). The selection module of cutting tool contains table of input parameters of design elements related with tables of cutting tool types. 
Larisa Simonova et al., International Journal of Emerging Trends in Engineering Research, 8(6), June 2020, 2774- 2778

Table 4a: Description of DE

\begin{tabular}{|c|l|l|l|l|l|l|l|l|l|}
\hline Hole & $\boldsymbol{\emptyset}_{\mathbf{1}}, \mathbf{m m}$ & $\mathbf{L}, \mathbf{m m}$ & $\boldsymbol{\emptyset}_{\mathbf{2}}, \mathbf{m m}$ & $\mathbf{R}_{\mathbf{g} \mathbf{r}}, \mathbf{m m}$ & $\mathbf{C}, \mathbf{m m}$ & $\mathbf{I T}$ & $\mathbf{R a} \boldsymbol{}$ & $\mathbf{I T}_{\mathbf{L}}$ & $\mathbf{R}_{\mathbf{L}, \mathbf{m m}}$ \\
\hline through & 1 & 1 & 0 & 0 & 0 & 1 & 1 & 0 & 0 \\
\hline bottom & 1 & 1 & 1 & 1 & 0 & 1 & 1 & 0 & 0 \\
\hline stepped & 1 & 1 & 1 & 1 & 1 & 1 & 1 & 0 & 1 \\
\hline threaded & 1 & 1 & 0 & 0 & 0 & 1 & 1 & 0 & 0 \\
\hline conical & 1 & 1 & 1 & 0 & 0 & 1 & 1 & 1 & 1 \\
\hline
\end{tabular}

The linguistic variables - Through hole, Bottom hole, Stepped hole, Threaded hole, Conical hole - are assigned to numerical values contained in the table of description of DE (Table 4a).

Selection of line in Table 4a depends on comparison of each cell of this table with the table of initial DE values (Table 1). The rule with fuzzy elements is as follows:
IF through hole THEN drill

IF bottom hole THEN drill

IF stepped hole THEN drill AND drill

IF threaded hole THEN drill AND punch

IF conical hole THEN drill AND reamer

The matrix (Tables $4 \mathrm{~b}$ and $4 \mathrm{c}$ ) contains design parameters of cutting tools.

Table 4b: Drill design parameters

\begin{tabular}{|c|l|l|l|l|l|l|l|}
\hline & $\begin{array}{l}\text { Diameter of } \\
\text { working } \\
\text { part, mm }\end{array}$ & $\begin{array}{l}\text { Working } \\
\text { length, mm }\end{array}$ & $\begin{array}{l}\text { Material of } \\
\text { working part }\end{array}$ & $\begin{array}{l}\text { Shank } \\
\text { diameter, } \\
\text { mm }\end{array}$ & $\begin{array}{l}\text { Total } \\
\text { length, } \\
\text { mm }\end{array}$ & Tip angle & $\begin{array}{l}\text { Resultant } \\
\text { precision }\end{array}$ \\
\hline $\begin{array}{c}\text { State standard } \\
\text { GOST 10902-77 } \\
\begin{array}{c}\text { Twist drills with } \\
\text { straight shank. }\end{array}\end{array}$ & 5 & 52 & $\begin{array}{l}\text { High-speed steel } \\
\text { HRC 63...65 }\end{array}$ & 86 & 118 & 6.3 \\
\hline
\end{tabular}

Table 4c: Mill design parameters

\begin{tabular}{|c|c|c|c|c|c|c|}
\hline & $\begin{array}{l}\begin{array}{l}\text { Diameter of } \\
\text { working part, } \\
\mathrm{mm}\end{array}\end{array}$ & $\begin{array}{l}\text { Working } \\
\text { length, mm }\end{array}$ & $\begin{array}{l}\text { Material of } \\
\text { working part }\end{array}$ & $\begin{array}{l}\text { Shank diameter, } \\
\mathrm{mm}\end{array}$ & $\begin{array}{l}\text { Total length, } \\
\mathrm{mm}\end{array}$ & $\begin{array}{l}\text { Number of } \\
\text { cutting bits }\end{array}$ \\
\hline $\begin{array}{c}\text { State standard } \\
\text { GOST 17025-71 } \\
\text { End mills with } \\
\text { cylindrical shank }\end{array}$ & 5 & 13 & $\begin{array}{l}\text { High-speed steel } \\
\text { HRC 63...65 }\end{array}$ & 5 & 47 & 4 \\
\hline
\end{tabular}

Engineering decision of selection module of cutting tool is as follows:

TR3 = end mill Ø $5 \mathrm{~mm}$ State standard GOST 17025-71

TR4= drill $\varnothing 5 \mathrm{~mm}$ State standard GOST 10902-77 end mill $\varnothing 5$ mm State standard GOST 17025-71

On the basis of formed engineering decision, the selection module of accessory and selection module of metal cutting equipment are initiated. The two modules of the intelligent system of engineering process design operate simultaneously, since the sizes of machine working zone directly influence the selection of accessory type. The tables of engineering capabilities of machine working zone are related with dimensions and accessory types [8].

Selection of optimum decision is comprised of searching for similar situations and adaptation of previous decision for new conditions. The case database contains all information about adopted decisions, that is, about previous events (cases), which estimate specific engineering routes. Therefore, on the basis of cases, final set of ranked alternatives is generated in the form of engineering decisions using design elements of item mechanical processing [9].

\section{SUMMARY}

Modules of adoption of engineering decisions in intelligent system of engineering processes operating according to the rules of fuzzy logics allow to use expert knowledge and to simulate engineering process under conditions of uncertainty [10].

\section{CONCLUSION}

This article has described the procedure of formation of engineering decisions in automatic modules of selection of processing routes, cutting tools, and metal cutting equipment in intelligent system of production process development. Linguistic variables have been defined and variable ranges have been preset using datasheets of engineering capabilities for each design module. Application of fuzzy rules under conditions of uncertainty allows to form automatically mechanical processing route of an item. 


\section{REFERENCES}

1. V.G. Shibakov. Intellektual'naya sistema formirovaniya tekhnologicheskikh protsessov shtampovochnogo proizvodstva na osnove CALS-tekhnologii [Intelligent system of formation of stamping processes based on CALS]. Ministry of Education and Science of the Russian Federation, Kama State Academy of Engineering and Economics. Moscow: Academia, 2011.

2. L. Simonova. Informatsionnoe obespechenie upravleniya tekhnologicheskimi marshrutami. Integrirovannye informatsionnye sistemy $\mathrm{v}$ mashinostroenii [Data support of process route management. Integrated data systems in engineering industry]. LAP Lambert Academic Publishing GmbH \& Co. KG, 2012.

3. L.A. Simonova, E.I. Egorova. Modular representation of the product in the knowledge base in the technological process formation. International Scientific Conference, 2015.

https://doi.org/10.1088/1757-899X/69/1/012042

4. L.A. Simonova, E.I. Egorova. Development of structural element precedent of technological process in computer-aided design. International Scientific Conference, 2015.

https://doi.org/10.1088/1757-899X/86/1/012017

5. E.I. Egorova, L.A. Simonova. Ontologicheskaya model' predstavleniya informatsii o tekhnologicheskom protsesse detali [Ontological model of data presentation about production process of an item]. Nauchno-tekhnicheskii vestnik Povolzh'ya no. 11, pp. 247-255, 2018.

6. L.A. Simonova, E.I. Egorova, A.I. Akhmadiev. Modul' formirovaniya marshrutov obrabotki poverkhnostei na osnove nechetkoi logiki [Modules of surface processing routes based on fuzzy logics]. Nauchno-tekhnicheskii vestnik Povolzh'ya no. 11, pp. 81-87, 2019.

7. E.I. Egorova. Representation of Information about Part on The Basis of Its Engineering Features. International Journal of Innovative Technology and Exploring Engineering vol. 8 no. 12, 2019.

https://doi.org/10.35940/ijitee.L3638.1081219

8. G.B. Evgenev. Intellektual'nye sistemy proektirovaniya [Intelligent design systems]: Guidebook. Moscow: Bauman MGTU, 2009.

9. G. Booch. Object-Oriented Analysis and Design with Applications. Boston: Addison Wesley Longman, 1994.

10. T.A. Gavrilova, V.F. Khoroshevskii. Bazy znanii intellektual'nykh sistem [Knowledge database of intelligent systems]. St. Petersburg: Piter, 2000. 